\title{
Effects of MCI-186 (Edaravone), a Novel Free Radical Scavenger, Upon Experimental Atherosclerosis in Apolipoprotein E-Deficient Mice
}

\author{
Taka-aki Okabe, BM; Chiharu Kishimoto, MD; Kana Shimada, BM; \\ Toshinori Murayama, MD; Masayuki Yokode, MD; Toru Kita, MD
}

\begin{abstract}
Background Recent evidence suggests that oxidative stress may play a role in the development of atherosclerosis. MCI-186 (3-methyl-1-phenyl-1-parazolin-5-one, edaravone) is a novel free radical scavenger, but it remains unclear whether free radical scavengers would be effective for the prevention of the disease.

Methods and Results Experimental atherosclerosis was induced in apolipoprotein E-deficient mice fed a highfat diet containing $0.3 \%$ cholesterol. Mice were treated with an intraperitoneal injection of either MCI-186 $1 \mathrm{mg} / \mathrm{kg}$ per day or MCI- $18610 \mathrm{mg} / \mathrm{kg}$ per day on alternate days over 4 weeks. Fatty streak lesion was suppressed by MCI- $18610 \mathrm{mg} / \mathrm{kg}$ per day administration, but not by $\mathrm{mg} / \mathrm{kg}$ per day. Immunohistochemical analysis showed that macrophage and $\mathrm{CD}^{+}{ }^{+} \mathrm{T}$-cell accumulation and oxidative stress overload in the fatty streak lesion were suppressed in mice that received MCI-186 treatment.

Conclusions MCI-186 administration suppressed the development of atherosclerosis, associated with reduced expression of both immune-activated cells and oxidative stress in fatty streak plaques. (Circ J 2006; 70: 12161219)
\end{abstract}

Key Words: Atherosclerosis; Free radical scavenger; Oxidative stress

$\Delta$

herosclerosis is associated with immune activation and inflammation ${ }^{1-3}$ Some investigations point to inflammatory/immune activation of plaques as a cause of acute coronary syndromes, 4,5 and have also suggested links between atherosclerosis and microbial infections.,6,7 Recently, it was suggested that oxidative stress may play a significant role in the development of atherosclerosis- -10

MCI-186 (3-methyl-1-phenyl-2-phyrazolin-5-one, edaravone) is a novel free radical scavenger ${ }^{11}$ that may be an effective agent for reducing tissue damage by inhibiting free radical production!2 Recently, we found that in apolipoprotein E (apo E)-deficient mice given immunoglobulin treatment (ie, immunosuppressive therapy), administered simultaneously with development of the disease, atherosclerosis was suppressed via the Fc portion! ${ }^{13,14}$ However, because it remains unclear whether the treatment with free radical scavengers would prevent atherosclerosis, we examined the effects of MCI-186 administration in an experimental atherosclerosis model.

\footnotetext{
Methods

Experimental Atherosclerosis

The apo E-deficient 129 ola $\times$ C57BL/6 hybrid mice were the generous gift of Dr Edward M. Rubin (University of

(Received April 5, 2006; revised manuscript received June 2, 2006; accepted June 21, 2006)

Department of Cardiovascular Medicine, Graduate School of Medicine, Kyoto University, Kyoto, Japan

Mailing address: Chiharu Kishimoto, MD, Department of Cardiovascular of Medicine, Graduate School of Medicine, Kyoto University, 54 Kawara-cho, Shogoin, Sakyo-ku, Kyoto 606-8507, Japan. E-mail: kkishi@kuhp.kyoto-u.ac.jp
}

California, Berkeley, CA, USA). They mice were mated with $\mathrm{C} 57 \mathrm{BL} / 6$ mice to produce $\mathrm{F}_{1}$ hybrids. The $\mathrm{F}_{1}$ apo $\mathrm{E}^{+-}$ mice were then backcrossed to C57BL/6 mice for 10 generations. Mice homogeneous for the apo E-null allele on a C57BL/6 background were subsequently generated and kept in a temperature-controlled facility on a 14.10-h light-dark cycle with free access to food and water. After being weaned at 4 weeks of age, the mice were fed a normal chow diet until 6 weeks of age, when they were switched to a high-fat diet containing 20\% fat and $0.3 \%$ cholesterol, as previously described $!^{13-15}$

All animal experiments were performed in accordance with the Declaration of Helsinki, and were approved by the institutional ethics committee for animal experiments.

\section{MCI-186 Treatment}

At 6 weeks of age, the mice were divided into 3 groups and treated with (1) vehicle (saline, $n=5$ ), (2) low-dose MCI-186 (1 mg/kg per day, n=5) (MCI-1), or (3) high-dose MCI-186 (10 mg/kg per day, $\mathrm{n}=5)$ (MCI-10), intraperitoneally 3 times per week (on alternate days) for 4 weeks. The administration route and dosages were determined from previous reports!1,12 MCI-186 was kindly supplied by

Table 1 Physiological Parameters

\begin{tabular}{lcccc}
\hline \hline & $n$ & $B W$ & $\begin{array}{c}T C \\
(\mathrm{mg} / \mathrm{dl})\end{array}$ & $\begin{array}{c}T G \\
(\mathrm{mg} / \mathrm{dl})\end{array}$ \\
\hline Control & 5 & $25.4 \pm 3.8$ & $689.3 \pm 86.7$ & $42.4 \pm 10.8$ \\
MCI 1 mg/kg per day & 5 & $23.7 \pm 2.6$ & $714.3 \pm 57.2$ & $51.1 \pm 18.7$ \\
MCI 10 mg/kg per day & 5 & $22.1 \pm 2.7$ & $704.3 \pm 74.8$ & $50.1 \pm 9.2$ \\
\hline
\end{tabular}

Data are mean $\pm S D$.

$B W$, body weight; TC, total cholesterol; $T G$, triglycerides. 

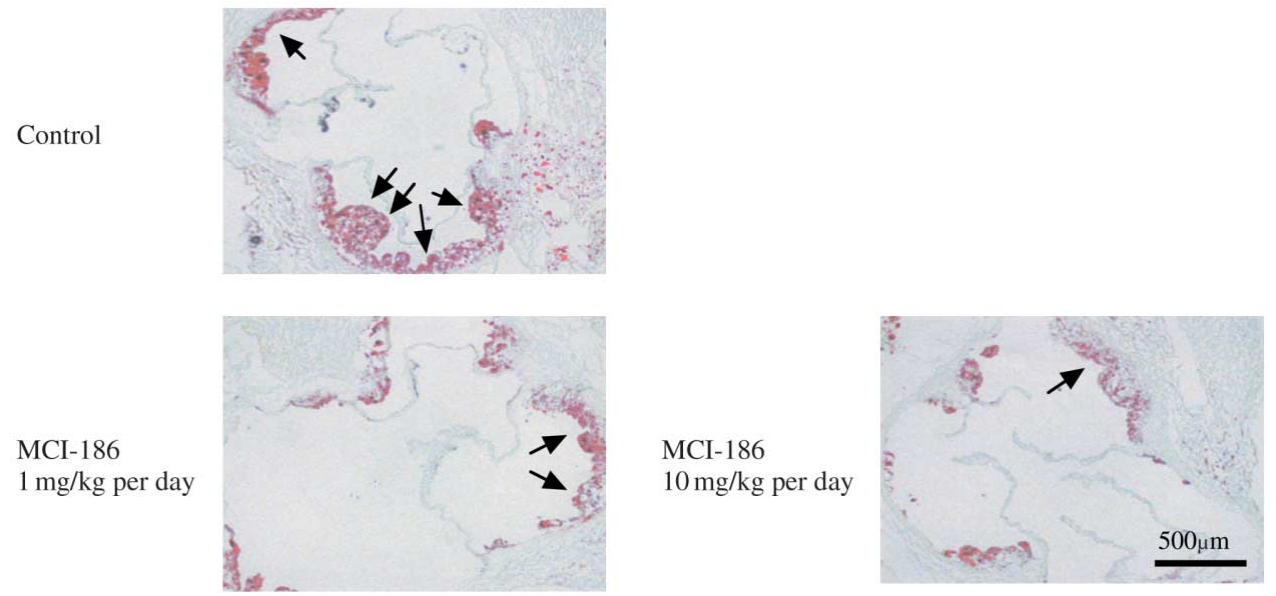

Fig 1. Effect of MCI-186 on atherosclerotic lesions. The lesions in the MCI-186-treated mice (arrows) were smaller and covered less of the inner circumference of the aortic root than those of the control mice (arrows) $(\times 40)$.

Mitsubishi Wellpharma Co Ltd (Tokyo, Japan).

\section{Tissue Processing}

Mice were killed by bleeding from a puncture of the right ventricle. The blood was collected and allowed to clot. After the serum was separated, lipid profiles were analyzed. The vasculature was perfused with sterile phosphatebuffered saline. The root of the aorta was dissected under a macroscope and frozen in OCT embedding medium for serial cryosectioning covering $1.0 \mathrm{~mm}$ of the root. The first section was harvested when the first cusp became visible in the lumen of the aorta. Four sections of $10 \mu \mathrm{m}$ thickness were harvested per slide, and thus 20 slides per mouse were prepared. All sections were immersed for $2 \mathrm{~min}$ in $60 \%$ isopropanol, stained for $15 \mathrm{~min}$ in a saturated oil red-O solution at $37^{\circ} \mathrm{C}$, counterstained with hematoxylin, and then mounted under coverslips with glycerol gelatin! ${ }^{3-15}$

\section{Quantitation of Atherosclerotic Lesions}

The oil red-O-stained sections were analyzed at a magnification of $\times 10$, as previously described ${ }^{13-15}$ The image was captured directly from the RGB camera attached to the light microscope and displayed on a microcomputer to quantify the cross-sectional surface area of the lesion and the cross-sectional surface area of the vessel. The fractional area of the lesion was calculated by dividing the whole vessel area, including the lumen, intima, media and adventitia, as previously described. For each animal, 20 sections (ie, every 4th section) were examined, and the mean of the fraction area was calculated ${ }^{3-16}$

\section{Immunohistochemistry}

Aortic root cryosections were processed for immunohistochemistry as described previously ${ }^{13-15}$ In brief, antimacrophage (anti-M $\varnothing, \mathrm{M} 3 / 84,1: 400$, PharMingen), antiCD4 (GK1.5, 1:50, PharMingen), anti-CD8 (53-6.7, 1:50, PharMingen), and anti-I-A $\mathrm{A}^{\mathrm{b}}$ (25-9-17, 1:25, PharMingen) antibodies were applied to acetone-fixed cryosections. After washing, the sections were then exposed to a second antibody (horseradish peroxidase-conjugated antibodies), and the antibody binding was visualized with diaminobenzidine. Sections were counterstained with $1 \%$ methyl green. The percentage of positively stained cells per infiltrating cells in the lesions was calculated for each antibody
Table 2 Quantitation of Atherosclerotic Lesions

\begin{tabular}{lcl}
\hline \hline & $n$ & Lesion area,$\mu \mathrm{m}^{2}(\%)$ \\
\hline Control & 5 & $84.5 \pm 16.4 \times 10^{3}(10.8 \pm 2.1)$ \\
MCI $1 \mathrm{mg} / \mathrm{kg}$ per day & 5 & $50.1 \pm 11.0 \times 10^{3}(6.4 \pm 1.4)$ \\
MCI 10 mg/kg per day & 5 & $39.1 \pm 13.3 \times 10^{3}(5.0 \pm 1.7) *$ \\
\hline
\end{tabular}

$*_{p}<0.01$ vs Control. Data are mean $\pm S D$.

Atherosclerotic lesions were suppressed in mice that received MCI-186 $10 \mathrm{mg} / \mathrm{kg}$ per day.

In contrast, atherosclerotic lesions were not ameliorated in mice that received $1 \mathrm{mg} / \mathrm{kg}$ per day.

as previously described; ${ }^{13-15}$ that is, lesions of the aortic root were analyzed. Data were obtained by dividing the number of positively stained cells by all methyl greenstained cells inside the internal elastic lamina. Three to 5 random microscopic fields were analyzed at $\times 200$. To analyze the oxidative stress overload in the aortic wall, immunohistochemistry for thioredoxin (TRX), which is a redox-active protein and considered a marker of oxidative stress, was performed as previously described ${ }^{17-19}$

\section{Serum Lipid Measurement}

Serum was separated by centrifugation and stored at $-80^{\circ} \mathrm{C}$. Serum total cholesterol and triglyceride levels were measured with assay kits (Wako) according to the manufacturer's instructions.

\section{Statistical Analysis}

Values are expressed as mean \pm SD. Statistical analysis of the data was determined by one-way ANOVA, followed by the Fisher protected least-significant-difference test. A value of $p<0.05$ was considered statistically significant.

\section{Results}

\section{Effects of MCI-186 on Physiological Parameters}

As shown in Table 1, treatment of MCI-186 did not significantly modify the serum lipid profiles. In addition, the drug did not reduce or increase body weight.

\section{Effects of MCI-186 on Fatty Streak Formation}

Controls developed extensive lesions in the root of the 
Table 3 Effects of MCI-186 Upon Inflammatory Cell and TRX Expression in Atherosclerotic Lesions

\begin{tabular}{lccc}
\hline \hline & Control & MCI-186 1 mg/kg per day & MCI-186 10mg/kg per day \\
\hline$M \phi(\%)$ & $23.3 \pm 4.9$ & $20.8 \pm 8.2$ & $15.0 \pm 7.2 *$ \\
$C D 4^{+}(\%)$ & $28.0 \pm 10.2$ & $22.3 \pm 7.6$ & $16.7 \pm 5.9 *$ \\
$C D 8^{+}(\%)$ & $9.2 \pm 3.6$ & $7.7 \pm 3.3$ & $5.9 \pm 4.7$ \\
$I-A^{b+}(\%)$ & $4.8 \pm 2.1$ & $3.9 \pm 2.5$ & $4.4 \pm 3.0$ \\
$T R X$ & ++++ & ++ & + \\
\hline
\end{tabular}

$* p<0.05$ vs Control. Data are mean $\pm S D$

$M \phi$, macrophage; TRX, thioredoxin.

Data were obtained by dividing the number of positively stained cells by all methyl green-stained cells inside the internal elastic lamina. Three to 5 random microscopic fields were analyzed at $\times 200$. Treatment with MCI-186 $10 \mathrm{mg} / \mathrm{kg}$ per day, but not $1 \mathrm{mg} / \mathrm{kg}$ per day, reduced the expression of both macrophages and $\mathrm{CD}^{+}$cells in the lesions.

TRX expression was suppressed by MCI-186 treatment. The grading of TRX expression was done semiquantitatively. Representative data from 3 distinct trials are shown.
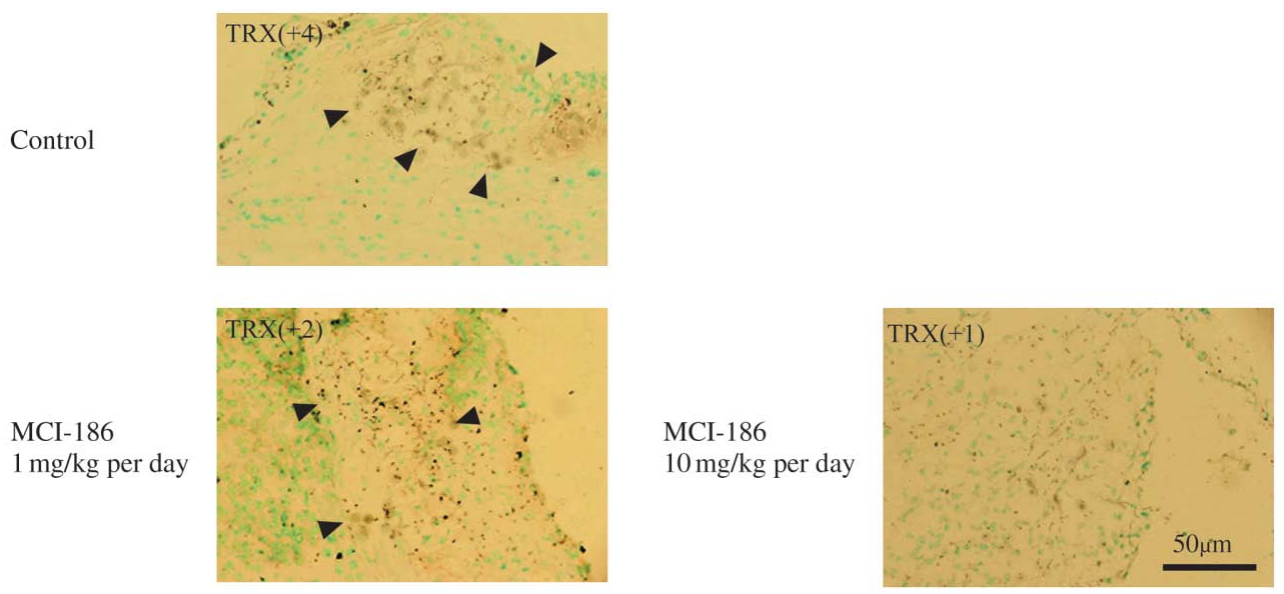

Fig 2. Effects of MCI-186 on oxidative stress. The expression of thioredoxin (TRX) in the lesions of the MCI-186treated mice was decreased compared with control mice. Brown staining (arrowheads) shows the positive area for TRX expression in the atherosclerotic plaques $(\times 200)$.

aorta. Fatty streak lesions were suppressed by MCI-186 $10 \mathrm{mg} / \mathrm{kg}$ per day administration, but not by $1 \mathrm{mg} / \mathrm{kg}$ per day (Fig 1). In mice treated with MCI-186 $10 \mathrm{mg} / \mathrm{kg}$ per day, the fractional area of the lesion was significantly reduced (Table 2).

\section{Effects of MCI-186 on Expression of Inflammatory Cells and Oxidative Stress in the Aortic Wall}

Macrophage and $\mathrm{CD}^{+}$cell accumulation in the fatty streak lesions was suppressed in mice receiving MCI-186 $10 \mathrm{mg} / \mathrm{kg}$ per day but not in those receiving $1 \mathrm{mg} / \mathrm{kg}$ per day (Table 3). TRX expression in the aortic walls was suppressed by MCI-186 treatment (Table 3, Fig 2).

\section{Discussion}

The present findings clearly demonstrated that MCI-186, a novel free radical scavenger, suppressed the severity of atherosclerosis in apoE-deficient mice, and that the atheroprotection conferred by MCI-186 may be related to its scavenging for free radicals in the aortic walls, possibly by the modification of oxidative stress.

Several studies have described the participation of free radicals in the pathogenesis of atherosclerosis ${ }^{8-10}$ In the present study, MCI-186 treatment suppressed the severity of experimental atherosclerosis. Immunohistochemical study showed that the intensity of TRX staining in the aortic wall was reduced by MCI-186 treatment. It has already been established that the degree of tissue TRX staining correlates with oxidative stress overload ${ }^{17-19}$ Accordingly, MCI-186 treatment of apoE-deficient mice protects against atherosclerosis by reducing oxidative stress.

In addition, MCI-186 suppressed not only the severity of atherosclerosis but also the inflammatory cell infiltrates in the fatty streak plaques. Recent evidence suggests that reactive oxygen species are involved in the antigen-presenting function of dendritic cells and immune effector cells, and that antioxidants suppress the activation of these cells ${ }^{20} \mathrm{In}$ another clinical model of myocarditis, it was reported that dendritic cells play a crucial role in the autoimmune process for the development of the disease? 1 Accordingly, MCI186 treatment resulted in a reduction of the autoimmune mechanisms by suppressing antigen-presentation by immune effector cells.

To date, there are no distinct protective agents for the prevention of atherosclerosis in the clinical setting. We have already reported that immunoglobulin administration, beginning simultaneously with the development of the disease, suppressed the lesions of an experimental atherosclerosis via the $\mathrm{Fc}$ portion ${ }^{13}$ Recent studies suggest that one mode of action of immunoglobulins is via the Foy receptor IIB, an inhibitory receptor, and that a large dose of immunoglobulins increases the expression of the $\mathrm{F}$ \% receptor IIB?22,23 We have confirmed that MCI-186 protects against acute murine experimental myocarditis by its free radical scavenging action, especially the hydroxyl radical scaveng- 
ing action 24 There is increasing evidence to support the critical role of free radicals in the development of atherosclerosis $^{8-10}$ and the rationale for prescribing MCI-186 in patients with atherosclerosis is based on its radical scavenging action and capacity to reduce immune-activated cell accumulation in the lesions. In the present study, MCI-186 treatment for 4 weeks ameliorated the experimental atherosclerosis. Accordingly, although there are some difficulties in practical use between the clinical and experimental settings, exploration of the usefulness of free radical scavengers in the treatment of atherosclerosis in humans appears warranted.

In conclusion, free radicals may be involved in the development of atherosclerosis. MCI-186 protected against experimental atherosclerosis in apoE-deficient mice by scavenging free radicals, resulting in reduced oxidative stress.

\section{References}

1. Ross R. Atherosclerosis: An inflammatory disease. $N$ Engl J Med 1999; 340: $115-126$.

2. Hansson GK. Immune mechanisms in atherosclerosis. Arterioscler Thromb Vasc Biol 2001; 21: 1876-1890.

3. Libby P, Hansson GK. Involvement of the immune system in human atherogenesis: Current knowledge and unanswered questions. Lab Invest 1991; 64: 5-15.

4. Kawashiri MA, Higashikata T, Takata M, Katsuda S, Miwa K, Nohara A, et al. Type III hyperlipoproteinemia exaggerated by Sheehan's syndrome with advanced systemic atherosclerosis. Circ J 2005; 69: 746-751.

5. Nasuno A, Matsubara T, Hori T, Higuchi K, Tsuchida K, Mezaki T, et al. Acute pulmonary thromboembolism induced by prophylactic heparin use and a heparin-coated catheter: A case of heparin-induced thrombocytopenia and thrombosis syndrome. Circ J 2003; 67: $96-$ 98.

6. Espinola-Klein C, Rupperecht HJ, Blankenberg S, Bickel C, Kopp H, Rippin G, et al. Impact of infectious burden on extent and longterm prognosis of atherosclerosis. Circulation 2002; 105: 15-21.

7. Memon RA, Staprans I, Noor M, Holleran WM, Uchida Y, Moser $\mathrm{AH}$, et al. Infection and inflammation induce LDL oxidation in vivo. Arterioscler Thromb Vasc Biol 2000; 20: 1536-1542.

8. Parthasarathy S, Santanam N, Ramachandran S, Meilhac O. Oxidants and antioxidants in atherogenesis: an appraisal. J Lipid Res 1999; 40: 2143-2157.

9. Bernal-Mizrachi C, Gates AC, Weng S, Imamura T, Knutsen RH, DeSantis $\mathrm{P}$, et al. Vascular respiratory uncoupling increases blood pressure and atherosclerosis. Nature 2005; 435: 502-506.

10. Franzoni F, Ghiadoni L, Galetta F, Plantinga Y, Lubrano V, Huang Y, et al. Physical activity, plasma antioxidant capacity, and endotheliumdependent vasodilation in young and older men. Am J Hypertens 2005; 18: 510-516.

11. Watanabe K, Hayase T. Radical scavenging mechanisms of MCI-186. Jpn Pharmacol Ther 1997; 25: 189-197.

12. Tada S, Nakamoto N, Kameyama K, Tsunematsu S, Kumagai N, Saito $\mathrm{H}$, et al. Clinical usefulness of edaravone for acute liver injury. J Gastroenterol Hepatol 2003; 18: 851-857.

13. Yuan Z, Kishimoto C, Sano H, Shioji K, Xu Y, Yokode M. Immunoglobulin treatment suppresses atherosclerosis in apolipoprotein Edeficient mice via the Fc portion. Am J Physiol 2003; 285: H899H906.

14. Okabe T, Kishimoto C, Shimada K, Murayama T, Yokode M, Kita T. Effects of immunoglobulin administration on experimental atherosclerosis in apolipoprotein E-deficient mice at subsequent stage. Circ J 2005; 69: 1543-1546.

15. Murayama T, Yokode M, Kataoka H, Imabayashi T, Yoshida H, Sano $\mathrm{H}$, et al. Intraperitoneal administration of anti-c-fms monoclonal antibody prevents initial events of atherogenesis but dose not reduce the size of advanced lesions in apolipoprotein E-deficient mice. Circulation 1999; 99: 1740-1746.

16. Nicoletti A, Kaveri S, Caligiuri G, Bariéty J, Hansson GK. Immunoglobulin treatment reduces atherosclerosis in apo E knockout mice. J Clin Invest 1998; 102: 910-918.

17. Shioji K, Kishimoto C, Nakamura H, Toyokuni S, Nakayama Y, Yodoi J, et al. Upregulation of thioredoxin (TRX) expression in giant cell myocarditis in rats. FEBS Lett 2000; 472: 109-113.

18. Yuan Z, Kishimoto C, Shioji K, Nakamura H, Yodoi J, Sasayama S. Temocapril treatment ameliorates autoimmune myocarditis associated with enhanced cardiomyocyte thioredoxin expression. Cardiovasc Res 2002; 55: 320-328.

19. Shioji K, Kishimoto C, Nakamura H, Masutani H, Yuan Z, Oka S, et al. Overexpression of thioredoxin in transgenic mice attenuates adriamycin-induced cardiotoxicity. Circulation 2002; 106: 1403 1409.

20. Matsue H, Edelbaum D, Shalhevet D, Mizumoto N, Yang C, Mummert ME, et al. Generation and function of reactive oxygen species in dendritic cells during antigen presentation. J Immunol 2003; 171: 3010-3018.

21. Shioji K, Kishimoto C, Sasayama S. Fc receptor-mediated inhibitory effect of immunoglobulin therapy on autoimmune giant cell myocarditis: Concomitant suppression of the expression of dendritic cells. Circ Res 2001; 89: 540-546.

22. Samuelsson A, Towers TL, Ravetch JV. Anti-inflammatory activity of IVIG mediated through the inhibitory Fc receptor. Science 2001; 291: $484-486$.

23. Mineo C, Gormley AK, Yuhanna IS, Osborne-Lawrence S, Gibson LL, Hahner L, et al. FcRIIB mediates C-reactive protein inhibition of endothelial NO synthase. Circ Res 2005; 112: 1016-1023.

24. Nimata M, Okabe T, Hattori M, Yuan Z, Shioji K, Kishimoto C. MCI-186 (edaravone), a novel free radical scavenger, protects against acute autoimmune myocarditis in rats. Am J Physiol 2005; 289: $\mathrm{H} 2514-\mathrm{H} 2518$. 